\title{
Investigation and Prioritizing the Effective Factors on Increasing the Human Resources Productivity in Agriculture Bank Using Multi-Attribute Decision Making Model
}

\author{
Amir Abachi ${ }^{1}$ \\ ${ }^{1}$ Research and Strategic Planning center of the Agricultural Bank of Iran, Iran \\ Correspondence: Amir Abachi, Research and Strategic Planning center of the Agricultural Bank of Iran, Iran. Tel: \\ 98-091-2187-3875. E-mail: abachi9494@gmail.com
}

Received: January 15, 2016

Accepted: January 31, 2016

Online Published: February 27, 2016

doi:10.5539/mas.v10n5p21

URL: http://dx.doi.org/10.5539/mas.v10n5p21

\begin{abstract}
As organizations are going to develop, the need for efficient manpower becomes more apparent. Obviously, productivity of the manpower requires the attention of managers to the complexity of human behavior and appropriate utilization of the principles, techniques and skills of the management. This study aims to prioritize the effective factors on productivity of human resources in the Agriculture Bank. Productivity is beyond the performance, it also contains the effectiveness concept, and in other words, productivity is not just doing the right things. An activity may be done correctly and in the best way, while it has no role in achieving the goal. In this case, the performance is available but there is no productivity. Difference between the performance and is rooted in the effectiveness or in the direction of doing a work. The current paper is a descriptive survey. Statistical population includes all experts in the Research and Strategic Planning center of the Agricultural Bank (33 persons). The data obtained from the questionnaire were analyzed using descriptive statistics in the form of frequency table. Questions were examined based on the one-group- t-test and using SPSS. Effective factors on increasing the human resources productivity were prioritized using Multi- Attribute Decision Making (MADM). After comparison of the alternatives, the related tables were prepared and prioritizing or ranking were done by determining the weight of each factor indexes and finally determining the weight of the four main factors. TOPSIS was used to evaluate the results of the MADM. Our research aims to prioritize the four factors according to the MADM.
\end{abstract}

Keywords: productivity, human resources, Multi-Attribute Decision Making model

\section{Introduction}

In the rapid changing and transformative today's world, all evidences indicate the centrality of the human resources role in creation of new technologies, production of various products and Opening the bottlenecks. In fact, the human resources form the basis of any organization. If these resources are with sufficient incentives, they will be used to develop the organization (Eshaq Hosseini, et al, 1998, pp. 8-9). Proper operation of organizations to realize the goals and economic, social and cultural development programs is of great importance. Presence of competent human resources that can be guided by effective managers and use the sources and facilities to achieve organizational goals is the most important factor in the productivity of organs in every society (Zahedi, 1996, p 5).

Göbel \& Zwick (2013) conducted a study on "personnel measures effective in increasing productivity of old workers" and concluded that the relative productivity contributions of old workers are significantly higher in establishments that provide either specific equipment of work places or age-specific jobs for old workers. In establishments that apply mixed-age workings teams the relative productivity contributions of old and of young employees are significantly higher than in establishments without this measure. They also found that Working time reductions and specific training for old employees are not associated with higher relative productivity of these employees.

Jaskiewicz \& Tulenko (2012) in their research on "Increasing community health worker productivity and effectiveness" concluded that an organized manner of carrying out tasks, a reasonable geographic distance to cover, the needed supplies and equipment, a supportive supervisor, and respect and acceptance from the 
community and the health system, they can function more productively and contribute to an effective community-based strategy

Familiarity of human with this concept is not a new issue and emergence of such perception despite uncertainty should be considered as a phenomenon coincided with human life on the earth historically. Regular scientific and statistical research on the issue of productivity initiated recently. It seems that the first attempts combined with scientific interpretation of the productivity started since the $18^{\text {th }}$ century, but there are different views about the way through which this term entered the economic literature. One of them is the viewpoint of "john Forstid" he believes that this term was introduced in ancients' works and in a book titled "Metallica" by "Agricola". But in the 18th century this concept was named as "the power of production" by physiocrats like François Quesnay. The "production" concept also was used in the Larousse dictionary in 1883 by Littre. Karl Marx who presented the Labor Theory of Value and Adam Smith as analyst of the labor relations and division of labor are among those who have played significant role in continuing the productivity concept (Tafazolli, 1993). Since the early twentieth century, a more precise concept was presented for this concept and factors used to produce it were defined. In 1900, a person called "Erli" defined the productivity as the relation between the productivity and tools used to produce it. Totally, it was defined more clearly as "measurable relationship between the production and its factors". Sohant in the "productivity engineering and management" book states the historical secrete of the productivity introduction in the form of table. He also is of the opinion that the François Quesnay was the first who introduced the productivity. The concept of productivity is complex while simplicity and is not still certainly perceived and there is no consensus on a comprehensive definition about this concept among experts. In 1950, the European Economic Cooperation Organization (OEEC) offered a more complete definition of the productivity: The quotient (ratio) obtained by dividing output by one of the factors of production. so that, productivity of capital, capitalization or raw materials can be named. Koopman believes that the productivity of human resources is influenced by 4 factors:

1. Environmental factors including cultural, social, political and ministerial condition.

2. organizational factors such as the level of employees' participation, employees compensation system, proper selection of staff, training programs, leadership methods, organizational structure, organizational supports and organizational culture.

3. job factors: contains availability of channels for timely correction of individual's performance outputs based on subjective criteria, designing program and scheduling which includes skills diversity, task identity, the importance of independence duty (freedom of action), feedback, job cognition and clear understanding of your role and awareness of career goals, availability of apparent job description and timely notice of the results of your performance. Personal factors include the level of knowledge and skills, job experience, abilities, beliefs, values, attitudes and motivations (Koopman, 1986).

4. Lack of staff's awareness of skills (technical, behavioral, intellectual and perceptual skills) and lack of awareness of managers of proper management methods turns them into the people who are merely implement the directives without ability to lead the staff's and the organization goals in the same direction using correct methods and mainly are extremists. In other words, they are task-oriented or employee-oriented. Hence, trying to identify those factors that ensure the productivity of human resources is significantly important and can result in other attempts to increase the productivity of human resources through training and other measures. Although there are many factors involved in achieving an organization to its goals, the role of human resources is unique and it can be said that there is logical link between the organizational productivity and human resources productivity provided that organizational productivity can be obtained through the productivity of human resources. Any research on measurement and improving the productivity of this system is considered as an effort effective in promoting the quality of human resources performance in organizations and has great importance.

\section{Material and Methods}

The current paper is a developmental-applied research considering the nature and objectives. This research aims to acquire required knowledge through which an identified need can be met. In this kind of research, the goal is to discover a new knowledge that follows a certain application of a product or process in reality. It means that, applied research is an effort to answer a practical problem available in the real world (Khaki, 2009). One of the applied research works in management is "investigating the reasons for inclusiveness of group work spirit among auto industry workers and offering solutions to make them inclusive. Since this research evaluates the current situation, is in the field of descriptive studies and since it evaluates the individuals' Preferences and opinions through questionnaire and multi- attitude decision making (MADM), it is a survey. Thus, it is a descriptive 
survey. Research and Strategic Planning center of the Agricultural Bank in 2015 is used in this study. The statistical population includes all experts (33) in the Research and Strategic Planning center of the Agricultural Bank. Considering that necessity of determining all effective factors on organizational productivity of the Agriculture Bank, ordinary methods such as mean, standard deviation and decision making methods will be used to analyze data descriptively, if necessary. The method of descriptive analysis will be used if sampling is done and researcher is going to generalize data from sample to population. In the case of sampling, applying the inferential statistics is required to determine the effective factors on the organizational productivity. Here, dependent variable is the productivity of human resources and the effective factors on the productivity (personal, job, organizational and environmental factors) are considered as independent variables. Questions of the questionnaire are analyzed using descriptive statistics in the form of frequency tables in data analysis section. Research questions are evaluated based on the one-group t-Test and using SPSS. Consequently, participants' opinions on the impact of personal, job, organizational and environmental factors on increasing the productivity of human resources are compared and assessed. The MADM is used to prioritize the effective factors on increasing the human resources productivity. In this method, related tables are prepared after comparing the two alternatives in each factor. Next, weights of indices in every factor are determined. Finally, prioritizing or ranking is done after weighting the 4 main factors. TOPSIS software is applied to calculate the results of the MADM model. Prioritizing the four factors using MADM model is considered.

\section{Results}

We evaluate the above mentioned factors using MADM model in the following. It should be noted that we use TOPSIS software for calculations in this section. In the model, selection of one alternative among other alternatives is possible considering the prioritization of alternatives. First step in prioritizing the components of a problem is done through paired comparisons which means that paired components are compared based on a criterion. Applying the matrix method is the best way for paired comparisons. This method is a simple and useful method that provides a framework to obtain more information through all possible comparisons and analysis of overall priorities with making changes in judgments. The paired comparisons begin from the top of the hierarchy by choosing the criterion of $C$. Afterwards, components $\left(A_{1}, A_{2}, A_{3} \ldots A_{n}\right)$ which should be compared are selected from the first underlying level of the criterion $\mathrm{C}$. the components are arranged in the matrix (figure 1).

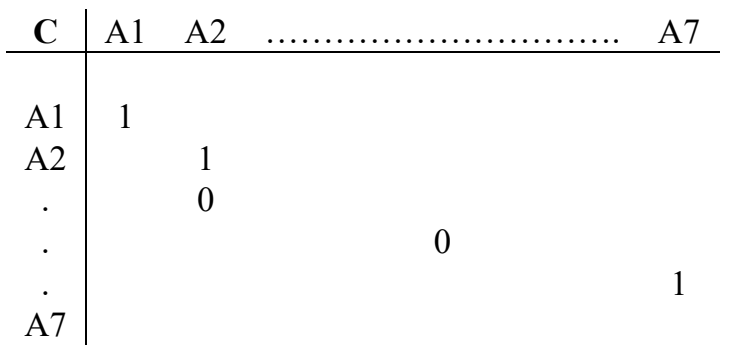

Figure 1. Paired comparisons matrix

In this matrix, $A_{1}$ element in the top column is compared with $A_{1}-A_{7}$ in rows based on the $C$ criterion in the left corner of the matrix. Then, this trend is repeated for $\mathrm{A}_{2}$ and other elements in the column. Numbers are used for filling the paired comparisons matrix to determine the relative importance of every element compared with other elements in association with the target property. Table (1) shows a scale for paired comparisons.

Table 1. Pairwise comparisons scale

\begin{tabular}{ll}
\hline Numerical value & Importance degree in paired comparisons \\
\hline 1 & Same preference \\
2 & Same or relatively preferred \\
3 & relatively preferred \\
4 & relatively up to strongly preferred \\
5 & Strongly preferred \\
6 & Strongly or very strongly preferred \\
7 & Very strong preference \\
8 & Highly or immeasurable preferred \\
9 & immeasurable preferred \\
\hline
\end{tabular}


Table (1) defines the value of numbers 1-9 related to the judgments (in paired comparisons). Experiences show that 9 -classes scale is logical and reflects degrees in a way that differences can be considered between the intensity of the relationship between the elements.

The number 1 is used when an element is compared with itself (comparison of A1 in the row with A1 in the column in the figure 1). Thus, the matrix diagonal is always is a set of numbers 1 . For other elements, the first element (an element in the left column of the matrix) is compared with the second element (an element in the top row) and the numerical value is estimated based on a scale available in the table (1). Its reverse value is then used to compare the second element with the first element. For example, if two elements are compared and the first element importance is two times more than the second element, the importance of the second element will be one fifth of the first element.

The number of required judgments for every table is obtained using $\left(\mathrm{n}^{2-\mathrm{n}}\right) / 2$. The table of paired comparisons in selecting the individual factor criterion is the table 1.

Table 2. Judgments matrix

\begin{tabular}{lllllll}
\hline Individual & $\begin{array}{l}\text { Educational } \\
\text { degree }\end{array}$ & $\begin{array}{l}\text { Experience } \\
\text { and skill }\end{array}$ & $\begin{array}{l}\text { Progress } \\
\text { possibility }\end{array}$ & $\begin{array}{l}\text { Respect to the } \\
\text { personality }\end{array}$ & $\begin{array}{l}\text { Attitude toward } \\
\text { organization }\end{array}$ & $\begin{array}{l}\text { Job } \\
\text { position }\end{array}$ \\
\hline $\begin{array}{l}\text { Educational } \\
\text { degrees }\end{array}$ & 1 & 7 & $1 / 5$ & 8 & 9 & 7 \\
$\begin{array}{l}\text { Experience } \\
\text { skill and }\end{array}$ & $1 / 7$ & 1 & 6 & 6 & $1 / 5$ & $1 / 8$ \\
$\begin{array}{l}\text { Progress } \\
\text { possibility }\end{array}$ & 5 & $1 / 6$ & 1 & 7 & $1 / 7$ & $1 / 7$ \\
$\begin{array}{l}\text { Respect to the } \\
\text { personality }\end{array}$ & $1 / 8$ & $1 / 6$ & $1 / 7$ & 1 & $1 / 7$ & $1 / 5$ \\
$\begin{array}{l}\text { Attitude toward } \\
\text { organization }\end{array}$ & $1 / 9$ & 5 & 7 & 7 & 1 & 7 \\
Job position & $1 / 7$ & 8 & 7 & 5 & $1 / 7$ & 1 \\
\hline
\end{tabular}

This table compares the educational degrees index with the other 5 indices for effective individual criterion in increasing the human resources productivity. 5 tables similar to this table are the result of paired comparison of the subsequent rows with other indices (appendix 1).

3 other criteria of the four factors including organizational, job and environmental factors are among effective factors on the productivity and will have such tables. There are 9,6 and 2 tables for organizational, job and environmental criteria, respectively.

\subsection{Integration of Judgments}

To develop a set of priorities for an issue, the judgments obtained using the paired comparisons should be combined. It means that, some operations should be done through which a number is obtained that represents the priority of every element. The performed judgments should be integrated to achieve the relative priority of every index according to the individual criterion. To do this, the elements of the column 1 row 2 in 6 tables are first added together, then the $10^{\text {th }}$ root of the total numbers of the column 1 , row 2 are placed in the combined individual table. Other blocks of the table are filled similarly. The diagonal of the table is still 1.

\subsection{Combined Table of the 10 Individual Matrices}

Table 3. Judgments combination table

\begin{tabular}{lllllll}
\hline & $\begin{array}{l}\text { Educational } \\
\text { degrees }\end{array}$ & $\begin{array}{l}\text { Educational } \\
\text { degrees }\end{array}$ & $\begin{array}{l}\text { Educational } \\
\text { degrees }\end{array}$ & $\begin{array}{l}\text { Educational } \\
\text { degrees }\end{array}$ & $\begin{array}{l}\text { Educational } \\
\text { degrees }\end{array}$ & $\begin{array}{l}\text { Educational } \\
\text { degrees }\end{array}$ \\
\hline $\begin{array}{l}\text { Educational } \\
\text { degrees }\end{array}$ & 1 & 0.5683 & 2.0651 & 1.6093 & 3.9617 & 3.8884 \\
$\begin{array}{l}\text { Experience and } \\
\text { skill }\end{array}$ & 1.7550 & 1 & 2.5251 & 0.8543 & 1.7264 & 0.428 \\
$\begin{array}{l}\text { Progress } \\
\text { possibility }\end{array}$ & 0.3926 & 0.3300 & 1 & 0.2800 & 3.7681 & 1.9390 \\
\hline
\end{tabular}




\begin{tabular}{lcccccc}
\hline $\begin{array}{l}\text { Respect to the } \\
\text { personality }\end{array}$ & 1.2384 & 1.1688 & 3.5630 & 1 & 1.9954 & 1.0764 \\
$\begin{array}{l}\text { Attitude } \\
\text { toward }\end{array}$ & 0.2519 & 0.5783 & 0.2647 & 0.4998 & 1 & 0.3370 \\
$\begin{array}{l}\text { organization } \\
\begin{array}{l}\text { Educational } \\
\text { success }\end{array}\end{array}$ & 0.2599 & 1.1840 & 1.0266 & 0.9276 & 2.9576 & 1 \\
total & 4.8978 & 4.8294 & 1.0444 & 5.171 & 15.4092 & 9.0836 \\
\hline
\end{tabular}

To obtain the relative priority of every index, numbers of each column are first added and then the numbers of every column are divided by the total numbers of the column. This matrix allows more significant comparison of the elements. Finally, numbers of every row is added together and their average value is calculated and the relative priority of every index is obtained.

Comparison of the individual factors and combination of 10 matrices table

Table 4. Weighted mean matrix

\begin{tabular}{lllllllll}
\hline & $\begin{array}{l}\text { Educational } \\
\text { degrees }\end{array}$ & $\begin{array}{l}\text { Educational } \\
\text { degrees }\end{array}$ & $\begin{array}{l}\text { Educational } \\
\text { degrees }\end{array}$ & $\begin{array}{l}\text { Educational } \\
\text { degrees }\end{array}$ & $\begin{array}{l}\text { Educational } \\
\text { degrees }\end{array}$ & $\begin{array}{l}\text { Educational } \\
\text { degrees }\end{array}$ & $\Sigma$ & $\Sigma / 6$ \\
\hline $\begin{array}{l}\text { Educational } \\
\text { degrees }\end{array}$ & 0.2041 & 0.1176 & 0.1977 & 0.3112 & 0.2570 & 0.4280 & 1.5156 & 0.2515 \\
$\begin{array}{l}\text { Experience and } \\
\text { skill }\end{array}$ & 0.3583 & 0.2070 & 0.2417 & 0.1612 & 0.1120 & 0.0927 & 1.1769 & 0.1961 \\
$\begin{array}{l}\text { Progress } \\
\text { possibility }\end{array}$ & 0.0801 & 0.0683 & 0.0957 & 0.0541 & 0.2445 & 0.2134 & 0.7561 & 0.1265 \\
$\begin{array}{l}\text { Respect to the } \\
\text { personality }\end{array}$ & 0.2528 & 0.2420 & 0.3411 & 0.1933 & 0.1294 & 0.1184 & 1.277 & 0.2118 \\
$\begin{array}{l}\text { Attitude toward } \\
\text { organization }\end{array}$ & 0.0514 & 0.1197 & 0.0253 & 0.966 & 0.0648 & 0.0370 & 0.3948 & 0.06 \\
\begin{tabular}{l} 
Job success \\
\hline
\end{tabular} & 0.0530 & 0.2451 & 0.982 & 0.1793 & 0.1919 & 0.1100 & 0.8775 & 0.14 \\
\hline
\end{tabular}

According to the table (4), the first priority in the individual factors is related to the educational degrees with $0.2515 \%$, the last priority belongs to the factor of attitude toward organization with $0.06 \%$.

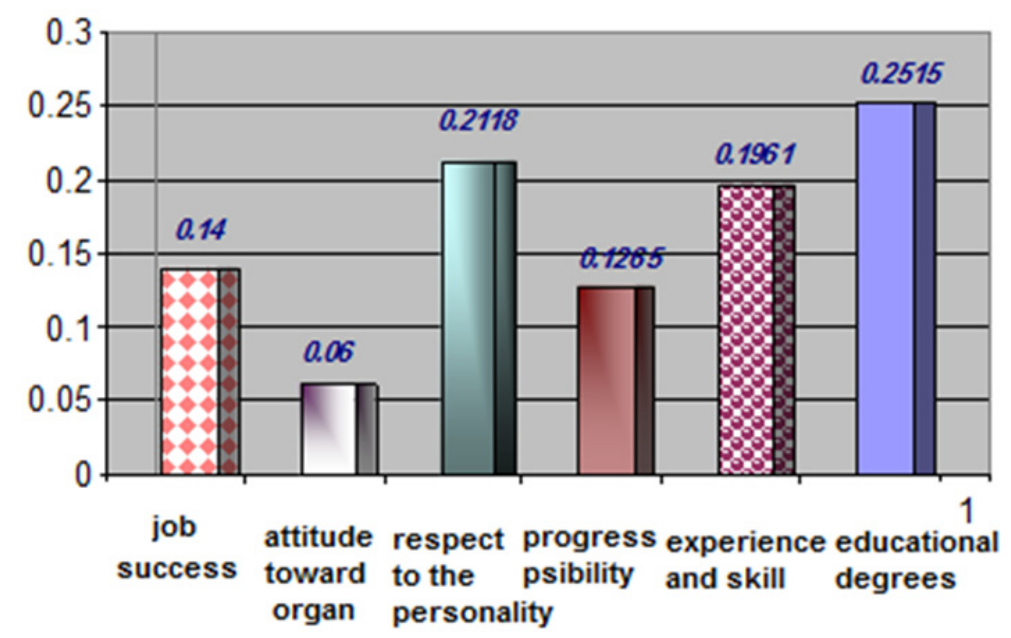

Figure 2. Prioritizing the individual factors indices effect on increasing the human resources productivity graph

The same process was carried out to prioritize the other factors effective on the productivity including organizational, job and environmental factors and the related tables for prioritizing the indices in every criterion are as follows, respectively: 
Prioritizing the organizational indices table

Weighted mean of the organizational indices table

Table 5. Weighted mean matrix

\begin{tabular}{|c|c|c|c|c|c|c|c|c|c|c|c|}
\hline & $\begin{array}{l}\text { Selection } \\
\text { and reward }\end{array}$ & $\begin{array}{c}\text { Salary } \\
\text { division }\end{array}$ & partnership & $\begin{array}{l}\text { Competent } \\
\text { managers }\end{array}$ & Equipment & responsibility & $\begin{array}{c}\text { Job } \\
\text { security }\end{array}$ & $\begin{array}{l}\text { Related } \\
\text { training }\end{array}$ & $\begin{array}{l}\text { Logical } \\
\text { division }\end{array}$ & $\Sigma$ & $\Sigma / 9$ \\
\hline selection & 0.1929 & 0.1719 & 0.1416 & 0.2615 & 0.1795 & 0.1499 & 0.1921 & 0.1096 & 0.1476 & 1.5439 & 0.1815 \\
\hline Salary system & 0.1042 & 0.1447 & 0.3247 & 0.1158 & 0.1520 & 0.1251 & 0.2528 & 0.087 & 0.1125 & 1.4186 & 0.1576 \\
\hline partnership & .1152 & 0.0376 & 0.0849 & 0.0839 & 0.0671 & 0.0929 & 0.1135 & 0.0759 & 0.1232 & 0.7942 & 0.0882 \\
\hline Competent & 0.0971 & 0.2717 & 0.1333 & 0.1322 & 0.2015 & 0.1991 & 0.0961 & 0.1476 & 0.1193 & 1.3925 & 0.1547 \\
\hline \multicolumn{12}{|l|}{ managers } \\
\hline equipment & 0.0493 & 0.0438 & 0.0583 & 0.0301 & 0.0462 & 0.0636 & 0.0800 & 0.0291 & 0.2741 & 0.4278 & 0.0475 \\
\hline responsibility & 0.0780 & 0.694 & 0.0343 & 0.0397 & 0.0406 & 0.0488 & 0.0620 & 0.0284 & 0.0465 & 0.4477 & 0.0497 \\
\hline Job security & 0.1246 & 0.0710 & 0.0929 & 0.1708 & 0.0717 & 0.1218 & 0.1245 & 0.3839 & 0.2360 & 1.3972 & 0.1552 \\
\hline Related training & 0.0929 & 0.929 & 0.0750 & 0.0740 & 0.1080 & 0.0977 & 0.0369 & 0.0829 & 0.1134 & 0.8299 & 0.0922 \\
\hline Logical division & 0.0897 & 0.9660 & 0.0545 & 0.0917 & 0.1331 & 0.1008 & 0.0417 & 0.0577 & 0.0792 & 0.745 & 0.0827 \\
\hline
\end{tabular}

According to the MADM model, the highest priority in the organizational factors is related to the index of "selection of individuals based on the competence" with $0.1751 \%$ and the last priority is related to the index of "provision of required equipment and facilities" with $0.0475 \%$.

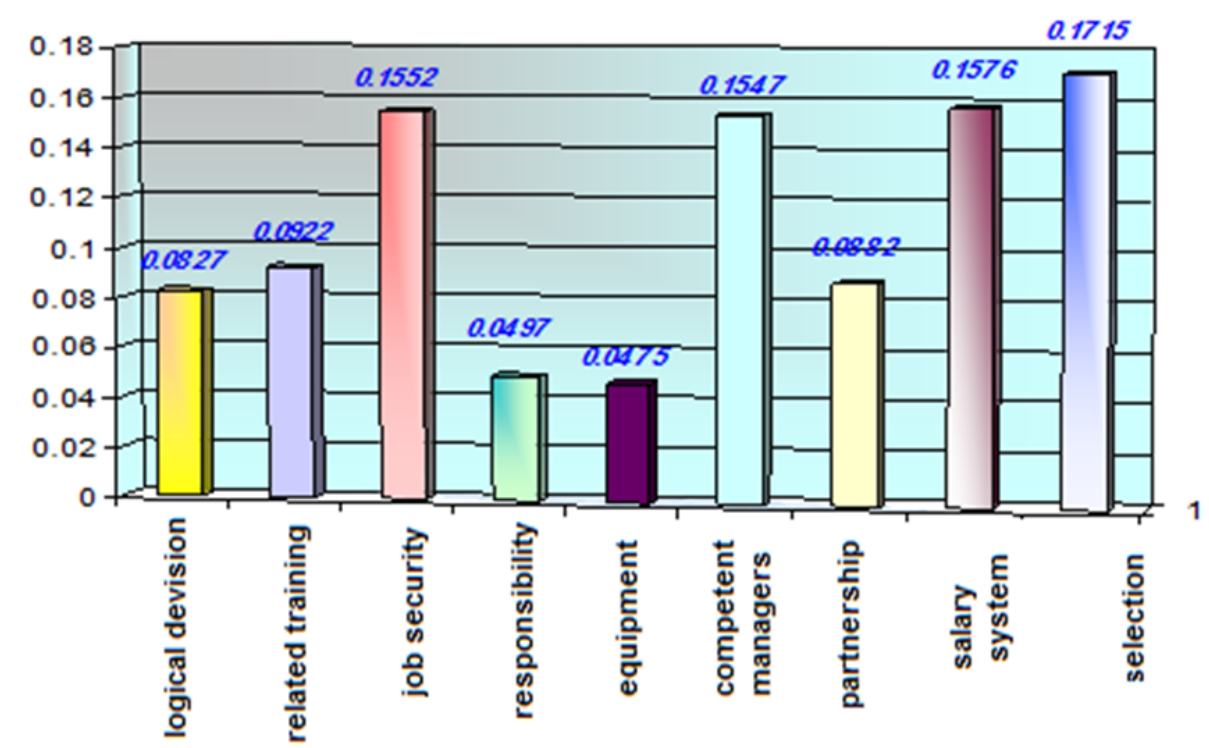

Figure 3. Ranking of the organizational factor indices effect on increasing the productivity of human resources graph

The table of prioritizing the environmental indices

The table of comparing the environmental factors and integration of 10 matrices

Table 6. Weighted mean matrix

\begin{tabular}{lllcl}
\hline & economic & Administrative & $\Sigma$ & $\Sigma / 2$ \\
\hline economic & 0.897 & 0.8090 & 1.6187 & 0.8093 \\
administrative & 0.1902 & 0.1909 & 0.3811 & 0.1905 \\
\hline
\end{tabular}

For environmental factors, the first priority belongs to the "economic status of the country" index with $0.8093 \%$ and the last priority is related to the "administrative status of the country" index with $0.1905 \%$. 


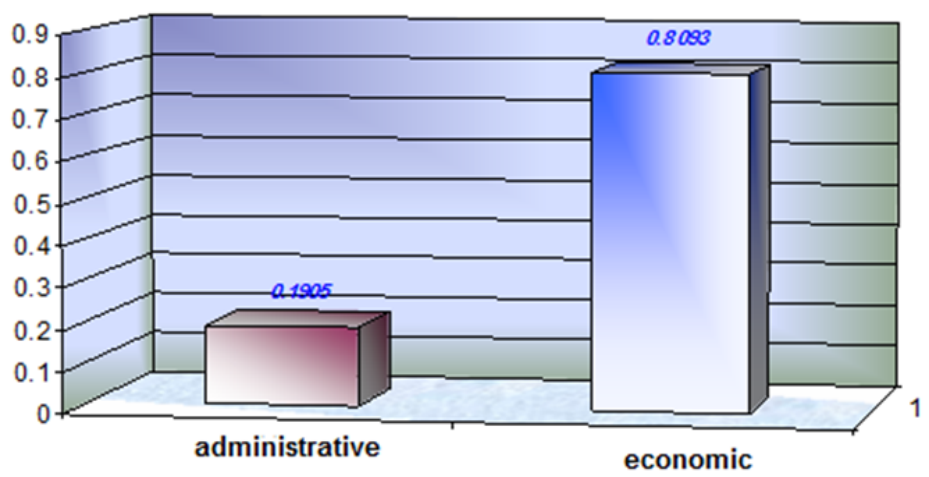

Figure 4. Ranking the environmental factors indices effect on increasing the productivity of human resources graph

The table of prioritizing the job indices

The table of comparing the job factors and 10 matrices

Table 7. Weighted mean matrix

\begin{tabular}{lllllllll}
\hline & $\begin{array}{l}\text { Awareness } \\
\text { goals }\end{array}$ & $\begin{array}{l}\text { of } \\
\text { job } \\
\text { description }\end{array}$ & $\begin{array}{l}\text { challenging } \\
\text { task }\end{array}$ & $\begin{array}{l}\text { freedom } \\
\text { action }\end{array}$ & $\begin{array}{l}\text { of } \\
\text { dutious }\end{array}$ & $\begin{array}{l}\text { Fair } \\
\text { assessment }\end{array}$ & $\Sigma$ & $\Sigma / 6$ \\
\hline $\begin{array}{l}\text { Awareness of } \\
\text { goals }\end{array}$ & 0.2007 & 0.2047 & 0.1944 & 0.1093 & 0.1228 & 0.1667 & 0.9986 & 0.1664 \\
job description & 0.2072 & 0.2116 & 0.3249 & 0.2286 & 0.2883 & 0.1725 & 1.6321 & 0.2388 \\
challenging task & 0.1167 & 0.0736 & 0.3211 & 0.1109 & 0.1491 & 0.1616 & 0.7251 & 0.1208 \\
freedom of & 0.0887 & 0.0997 & 0.0913 & 0.1078 & 0.0986 & 0.0909 & 0.0577 & 0.0961 \\
action & & & & & & & & \\
various duties & 0.0721 & 0.0900 & 0.0931 & 0.1340 & 0.1228 & 0.1468 & 0.6588 & 0.1098 \\
fair assessment & 0.3142 & 0.3201 & 0.1829 & 0.3092 & 0.2182 & 0.2613 & 1.6059 & 0.2676 \\
\hline
\end{tabular}

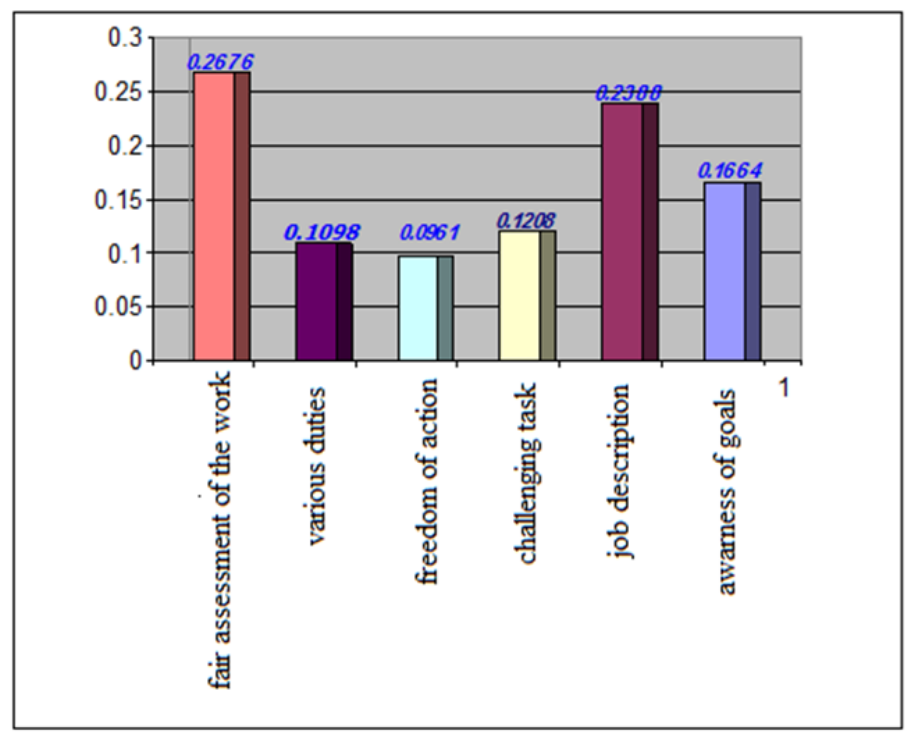

Figure 5. Ranking the job factors indices effect on increasing the productivity of human resources

In the job factors, the first priority is given to the index of "fair assessment of work and expression of individual's strengths and weaknesses honestly" with $0.2676 \%$ and the last priority belongs to the "freedom of action in work and decision making" index with $0.0961 \%$. 
Examining the research hypotheses

Hypothesis 1: organizational factors have the first priority in the productivity of human resources

Hypothesis 2: individual factors have the second priority in the productivity of human resources

Hypothesis 3: job factors have the third priority in productivity of human resources

Hypothesis 4: environmental factors have the fourth priority in productivity of human resources

The table of prioritizing the effective factors on increasing the productivity of human resources

The table of comparing the four factors of the productivity

Table 8 . Weighted values of the four factors

\begin{tabular}{lllllcc}
\hline factors & individual & job & environmental & organizational & $\Sigma$ & $\Sigma / 6$ \\
\hline Individual & 0.5123 & 0.4810 & 0.3483 & 0.5123 & 1.8853 & 0.47 \\
Job & 0.1426 & 0.1610 & 0.3573 & 0.1426 & 0.7567 & 0.18 \\
Environmental & 0.1744 & 0.0534 & 0.1187 & 0.1744 & 0.5256 & 0.13 \\
organizational & 0.1705 & 0.3044 & 0.1754 & 0.1705 & 0.8316 & 0.20 \\
\hline
\end{tabular}

According to the results of the comparing the criteria in the MADM model, first priority is for the individual factor with $0.47 \%$ and last priority is for environmental factor with $0.13 \%$. Therefore from the responders' views, prioritizing the four factors has not affected the productivity of human resources equally and the most impact is related to the individual factor and least impact is related to the environmental factors.

Hypothesis 1: organizational factors have the first priority in the productivity of human resources

Results of the table shows that the observed value of the mean organizational factor has the second priority in productivity of human resources compared with the other effective factors on productivity. Thus, the hypothesis 1 representing the priority of the organizational factor is rejected and it can't be claimed that organizational factors have the first priority in prioritizing the effective factors on productivity of human resources.

Hypothesis 2: individual factors have the second priority in productivity of human resources.

based on the average comments of the participants on the effect of individual factors and results of the prioritizing available in the table 8 , individual factors have the first priority. Thus, the hypothesis 2 of this research is rejected based on the prioritizing results.

Hypothesis 3: job factors have the third priority in productivity of human resources

results of the table indicates that based on the average score of the participants on the level of job factors effect on increasing the productivity of human resources, this factor is in the third priority in ranking and this hypothesis is accepted.

Hypothesis 4: environmental factors have the fourth priority in productivity of human resources

Environmental factors have the fourth priority based on the results of mean comments of the participants on the effect of environmental factors and this hypothesis is accepted.

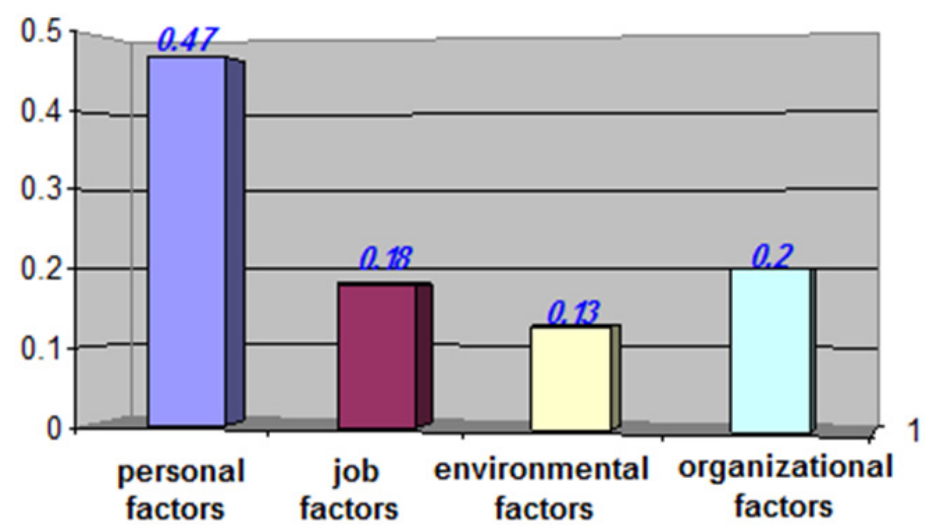

Figure 6. Ranking of four factors in increasing the productivity of human resources 


\section{Conclusion}

The following results are extracted based on the analyses of this research data:

All four mentioned factors (individual, environmental, job and organizational factors) influence the productivity of human resources. evaluation of the obtained results indicate that participants know the individual factors including respect to the personality, the level of experience and skills, educational degrees are the most important factor in increasing the productivity of human resources based on the multi attitude decision making model and paired comparison and it can be concluded that this factor plays great role in productivity of human resources. Moreover, organizational factors including presence of competent managers who can provide an environment for progress, selection based on reward and educations related to the job, availability of fairly reward system and so have significant role in productivity of human resources.

Using statistical method as MADM method in prioritizing the four effective factors on increasing the productivity is with high accuracy since factors were compared in pairs using pairwise comparison. This model prioritizes the factors different from other studies. Thus, achieved results can't be compared with the results of other studies.

Prioritizing the subset of individual factors based on the importance degree

\begin{tabular}{ll}
\hline & Question \\
\hline 1 & Educational degrees \\
2 & Respect to your personality in workplace \\
3 & The level of experience and skills associated with the job \\
4 & Gaining the career success \\
5 & The possibility of career progress \\
6 & Your attitude toward the job and organization \\
\hline
\end{tabular}

Prioritizing the subset of job factors based on the importance degree

\begin{tabular}{ll}
\hline & Question \\
\hline 1 & Economic status of the country (inflation, unemployment) \\
2 & Administrative status of the country (overall management style in the country) \\
\hline
\end{tabular}

Prioritizing the subset of organizational factors based on the importance degree

\begin{tabular}{ll}
\hline & Question \\
\hline 1 & Selection of personnel based on the competence principle \\
2 & Availability of fair salary and wage system based on the competence and effort level \\
3 & Creation of job security of selection \\
4 & Presence of efficient and competent managers in the organization \\
5 & Trainings which can increase the technical knowledge related to your job \\
6 & Your participation in decision making related to your job \\
7 & Correct and rational division of duties based on expertise \\
8 & Increasing the level of responsibility \\
9 & Providing facilities and equipment required to do tasks \\
\hline
\end{tabular}

Prioritizing the subset of job factors based on the importance level

\begin{tabular}{ll}
\hline & Question \\
\hline 1 & To assess your work fairly and let you know your weaknesses and strengths \\
2 & Availability of clear job description \\
3 & Awareness of career goals and duties and understanding their importance \\
4 & Challenging works (works which doesn't have same trend) \\
5 & Diverse and widespread job duties \\
6 & To have freedom of action in work and decisions makings related to your job \\
\hline
\end{tabular}




\section{Recommendations}

1. Results show that from the view of participants, the individual factors are important in increasing the productivity of human resources. Hence, it is critical to make decisions on selection and appointment of staff based on competent and to determine standard conditions for qualifying different jobs according to the essential competencies for each job considering the indices and sub-criteria of this factor.

2. Since the organizational factors have significant role in productivity of human resources, it is necessary to pay attention to the employment, salary, training and development, improvement of human resources policies and to emphasis on selection of managers based on competencies.

3. Results show the job factors including awareness of objectives and job duties and understanding their importance, the feeling of having an important job, having freedom of action in decision making and doing tasks, taking advantage of all your skills and knowledge, diverse and extensive job duties and awareness of goals and job duties and understanding the importance have most influence on increasing the productivity of human resources. Moreover, participants believe that if they have clear understanding of main goals and know how to do their tasks, they will be more responsible in the workplace. It is recommended to make aware the managers and staff of long-term, short term and mid-term goals and organizational and environmental preferences through adoption of appropriate partnership and involving them in decision making. Justifying trainings can be useful in this regard.

4. Considering that environmental factors includes social status such as (population growth rate, sanitary ...), economic condition (inflation, unemployment ...), political status (political stability) and administrative status (management style in the whole country), it is recommended to take into account the external and environmental factors of the organization in addition to the internal factors of the organization. It means to increase the negative effect of external factors by adopting appropriate decisions and taking necessary measures in the workplace.

5. Since all four mentioned factors (individual, environmental, job and organizational factors) influence the productivity of human resources, managers and staff should not just rely on one factor, instead they should consider all variables and balance the decisions and necessary policies through proper recognition of the impact and importance of each group of factors.

\section{References}

Azar, A., \& Rajabzadeh, A. (2008). Applied decision making, MADM approach, Negah danesh press, Tehran.

BazazJazayeri, S. A. (1994). Staff training as an identified necessity in administrative and industrial organs, Scientific-Applied Journal of Governmental Management, 26-17.

Best, J. W. (1987). Research methods in behavioral and educative sciences (Hassan Pasha Sharifi \& Narges Taleqani trans.), Tehran, Roshd press.

Göbel, C., \& Zwick, T. (2013). Are personnel measures effective in increasing productivity of old workers? Labour Economics, 22, 80-93.

Jaskiewicz, W., \& Tulenko, K. (2012). Increasing community health worker productivity and effectiveness: a review of the influence of the work environment. Hum Resour Health, 10(1), 38.

Khaki, G. R. (2009). Productivity management, Koohsar press, Tehran.

Lothans, F. (1993). Organizational behavior, (Sarmadi trans.), Banking Institute press, Tehran.

Paul, H., \& Kentich, B. (1994). Management of organizational behavior (Qasem Kabiri trans), Jahad Daneshgahi press, Tehran.

Poyan, S. A., \& Masoumi, M. (2009). Establishment of productivity cycle, 7th Conference on Quality \& productivity.

Rezaeean, A. (1994). Tehran University press.

Richard, A., Johnson., Gouri, K., \& Bhatta, C. (2003). (Fatah Mikaeeli trans), Arkan press, Tehran. June 2014

Sarmad, Z., Bazargan, A., \& Hejazi, E. (1997). Research methods in behavioral science, Agah press, Tehran.

Shavelson, R. (2006). Statistical reasoning in behavioral sciences, (Ali Kiamanesh trans.), Tehran Jahad Daneshgahi, 2.

Taheri, S. (2001). Productivity and its analysis in organizations, Havaye Tazeh press, Tehran. 
Taleqani, G., Tanaomi, M. M., Farhangi, A. A., \& Zarrinnegar, M. J. ( 2011). Investigation of effective factors on productivity incensement (case study, Saman bank). Governmental Management Quarterly Journal, 7.

\section{Copyrights}

Copyright for this article is retained by the author(s), with first publication rights granted to the journal.

This is an open-access article distributed under the terms and conditions of the Creative Commons Attribution license (http://creativecommons.org/licenses/by/3.0/). 